\title{
Nodular lichen myxedematosus
}

INSERM

\section{Source}

INSERM. (1999). Orphanet: an online rare disease and orphan drug data base. Nodular lichen myxedematosus. ORPHA:90393

Nodular lichen myxedematosus is a rare form of localized lichen myxedematosus (see this term) characterized by the development of skin-coloured mucinous nodules on the limbs and trunk, with mild or absent papular eruption. 